\title{
Kant, Hegel, Foucault e a Desrazão na História: o CÂnone Filosófico de História da LOUCURA ${ }^{1}$
}

\author{
Tomás Prado
}

\begin{abstract}
RESUMO: Este artigo propôe relacionar as filosofias da história de Kant e de Hegel às bases do pensamento de Foucault, em História da loucura na idade clássica. Buscamos reconhecer, náo indícios de uma história cosmopolita ou universal, mas em que medida o pensamento crítico e a filosofia como ciência das essências puras comparecem na inteligibilidade histórica de Foucault. A reuniāo de uma diversidade de experiências sob o conceito de desatino (déraison, desrazão), fio condutor da obra, sugere uma proximidade com a tradição. Por outro lado, a falta de um critério intrínseco, o qual justifique a referência de tal multiplicidade à alcunha da loucura, faz com que o fio condutor se restrinja a um aspecto negativo e que, positivamente, Foucault estabeleça para seu trabalho um primado empírico, na forma de uma constelação de imagens. O procedimento de História da loucura, que, junto ao interesse pela desrazão, inaugura o privilégio dado pelo filósofo francês à análise das descontinuidades nos leva a reconhecer a razão com base nos casos que solapam aos seus limites, às essências por ela própria discernidas, e com base nas práticas por ela promovidas e justificadas.
\end{abstract}

PALAVRAS-CHAVE: Razão. Desrazão. Loucura. Filosofia. História.

\section{O ILUMINISMO E A FILOSOFIA CRÍTICA}

Duzentos anos após Kant responder à questão "O que é o Iluminismo?”, Foucault a retoma em um texto homônimo, dirigido à edição The Foucault reader, organizada em sua homenagem por Paul Rabinow. $\mathrm{O}$ ano de 1984 é o mesmo de sua morte, sendo essa uma das últimas ocasióes em que o filósofo de História da loucura apresenta um panorama de sua obra.

O interesse de Foucault na questão se deve à dupla preocupação kantiana, de entender a atualidade e de esclarecer a tarefa filosófica - e ao modo como Kant a insere no horizonte aberto pelo entendimento da atualidade.

\footnotetext{
${ }^{1}$ Esta pesquisa contou com o apoio do CNPq, no período de doutorado e da Capes, no período de doutorado-sanduíche.

${ }^{2}$ Professor de graduação e mestrado na Universidade São Judas Tadeu, em São Paulo. Doutor em Filosofia pela PUC-Rio, com experiência de pesquisa na Université Paris I Panthéon-Sorbonne. Email: tomprado@uol.com.br
} 
Porém, a sua análise não consiste em um respaldo ao sistema kantiano, mas no reconhecimento do compromisso com o presente. A metáfora kantiana da idade da razão, como superação da menoridade na qual o sujeito é conduzido por impressões herdadas e sob uma relação de autoridade, não lhe sugere a conquista de uma nova era na qual o uso público da razão e a partilha do conhecimento sejam valorizados, mas a defesa de um novo empenho ou atitude de pôr, a cada vez, o conhecimento à prova. A modernidade é, então, menos uma época alcançada do que o momento em que uma tarefa contínua é admitida. O que a caracteriza é a preocupação com a atualidade como horizonte para uma experiência que deve ser, a cada vez, própria.

É Baudelaire - “[...] uma das consciências mais agudas da modernidade" (FOUCAULT, 2008, p. 342) - quem melhor representa para Foucault a atitude moderna. Todavia, esse é um dos casos em que o vemos se reconhecer na tradição filosófica, e em que oferece critérios, os quais, uma vez estendidos a outros textos, nos permitem compreender o seu vínculo com a filosofia, com o "[...] êthos filosófico que seria possível caracterizar como crítica permanente de nosso ser histórico" (FOUCAULT, 2008, p. 345).

Nas palavras que, desse derradeiro ponto de seu trabalho, resumem o projeto global e que a um tempo o aproximam e o distinguem da filosofia de Kant:

Esse êthos filosófico pode ser caracterizado como uma atitude-limite. Não se trata de um comportamento de rejeição. Deve-se escapar à alternativa do fora e do dentro; é preciso situar-se nas fronteiras. A crítica é certamente a análise dos limites e a reflexão sobre eles. Mas, se a questão kantiana era saber a que limites o conhecimento deve renunciar a transpor, parece-me que, atualmente, a questáo crítica deve ser revertida em uma questáo positiva: no que nos é apresentado como universal, necessário, obrigatório, qual é a parte do que é singular, contingente e fruto das imposiçóes arbitrárias. Trata-se, em suma, de transformar a crítica exercida sob a forma de limitação necessária em uma crítica prática sob a forma de ultrapassagem possível. (FOUCAULT, 2008, p. 345).

A Crítica da razão pura, obra capital de Kant, volta-se aos limites do conhecimento científico frente às especulações transcendentes, sendo, ambos, resultado de nossa inclinação natural à metafísica. ${ }^{3}$ A questâo kantiana, que quer

\footnotetext{
3 "Em todos os homens, desde que neles a razão esteja acima da especulação, houve sempre e continuará a haver uma metafísica” (KANT, 2003, p. 56).
} 
ao mesmo tempo salvá-la e discriminar suas formas equivocadas, é: "De que forma é possível haver uma metafísica como ciência?” (KANT, 2003, p. 57)

A travessia possível das nossas limitações, da qual nos fala Foucault, é, por outro lado, empreendida por meio de uma reconsideraçáo de experiências do passado que foram subestimadas e esquecidas, tornando-as novamente valiosas ao presente. Vemos o exemplo dos estudos da prática de si, a askésis grega e romana, elaborados apenas dois anos antes, em $A$ hermenêutica do sujeito, quando Foucault recupera uma longa tradição de textos da Antiguidade aos quais hoje não atribuímos, em geral, uma importância central, dentre os quais se destacam o Alcibiades, de Platão, e, no estoicismo, as cartas de Sêneca e de Marco Aurélio. Enquanto a atualidade é, para Kant, uma oportunidade de discernir as nossas capacidades de circunscrever o domínio das coisas e, com base nessa organização, edificar o conhecimento seguro do mundo, para Foucault, a atualidade contém a configuraçáo hegemônica de uma experiência, a qual devemos não apenas pôr à prova nos domínios de conhecimento em que essa configuração geral submeteu à sua forma, como também quebrar essa hegemonia quando necessário, de maneira a resgatar outras experiências e restituir a legitimidade de seus caminhos interrompidos. Por exemplo, conforme vemos em $A$ hermenêutica do sujeito, contra a compreensão do sujeito como um conjunto de faculdades de conhecimento dadas a priori, trata-se de tomá-lo em seus modos de subjetivação pelos outros e por si mesmo, segundo a askésis grega, a prática de si. De tal rememoração em favor do alargamento de nossa liberdade de pensamento e de ação se dá a "crítica prática sob a forma de ultrapassagem possível”.

Em grande medida, Foucault admitirá critérios distintos daqueles de Kant, a fim de discernir artifícios metafísicos para um pensamento que se pretende crítico, de sorte que se trata de empregar a atitude qualificada por Kant à experiência hegemônica de pensamento na qual o próprio Kant se insere. É a atitude crítica, e não a forma como cada um descreve a sua atualidade e nela compreende a sua tarefa, que faz ambos presentes na mesma modernidade.

O pressuposto kantiano, em Ideia de uma história universal de um ponto de vista cosmopolita, é o seguinte: "De um ponto de vista metafísico, qualquer que seja o conceito que se faça da liberdade da vontade, as suas manifestaçóes - as açóes humanas -, como todo outro acontecimento natural, são determinadas por leis naturais universais" (KANT, 2011, p. 3). Se, no plano individual, os homens possuem arbítrio, globalmente, de uma perspectiva cosmopolita, pertencemos a um desenvolvimento constante e regular da espécie segundo 
determinaçóes naturais. De acordo com a sua descrição desse "fio condutor", as manifestações "[...] de tolice (na versão em francês, folie, loucura), capricho pueril e frequentemente também de maldade infantil e vandalismo" (KANT, 2011, p. 4), daquilo que talvez pudéssemos chamar "a desrazão na história”, seriam eventos casuais incapazes de alterar o curso do progresso real traçado pela natureza. Na quarta proposição da obra, percebemos que mesmo o antagonismo entre os homens tem uma função no sistema metafísico, a de servir de motor ao uso da razão - com o que muitas tragédias encontrariam a justificação de servir ao bem-estar das geraçôes futuras. ${ }^{4}$

Kant parece subestimar a história empírica, os eventos e os marcos que tratam dos fracassos e dos horrores produzidos pela humanidade, em favor da hegemonia de uma abstração racional que os contraria, abstração que melhor serve às nossas esperanças, às vezes mais pueris do que nossos erros. Desse modo, as guerras, como aquelas do imperialismo napoleônico, as quais the causariam grande decepção, seriam um tropeço em nossa história. Uma das grandes diferenças entre o pensamento produzido no século XX com relação àqueles voltados à história, durante os séculos XVIII e XIX, decorre dos efeitos traumáticos que as duas guerras mundiais produziram em nossos contemporâneos, infiltrando-se na filosofia com uma força capaz de sobrepor-se às discriminaçóes do que antes parecia acidental e ao deslumbre com a esperança até então incutida pela ciência nos homens, sobretudo durante o Iluminismo. Será às manifestaçôes que escapam dos planos traçados pelas "filosofias da história" que Foucault dará mais atenção.

Em Kant, a noção que guia a seleção dos acontecimentos históricos essenciais possui o nome de "doutrina teleológica da natureza”, na qual se estabelece que "[...] todas as disposiçôes naturais de uma criatura estão destinadas a um dia se desenvolver completamente e conforme um fim" (KANT, 2011, p. 5). Contra o fatalismo a que pode nos conduzir a constatação de nossos erros, seria preciso entrever um quadro maior de progresso, o qual nos levaria a "[...] um Estado cosmopolita universal, como o seio no qual pode se desenvolver todas as disposiçóes originais da espécie humana” (KANT, 2011, p. 19), especialmente a liberdade para a escolha moral, que haveria de nos recompensar com a "paz perpétua" e a "felicidade universal". Com efeito, a barbárie com a qual nos deparamos no século XX nos fez abdicar de um esforço de alçar tão

\footnotetext{
4 "O meio de que a natureza se serve para realizar o desenvolvimento de todas as suas disposiçôes é o antagonismo delas na sociedade, na medida em que ele se torna ao fim a causa de uma ordem regulada por leis desta sociedade" (KANT, 2011, p. 8).
} 
longinquamente o pensamento ao encontro desse refúgio. No lugar de assim nos empenharmos, buscamos compreender as condiçóes produtoras das crises, como se vê nas obras de Adorno e de Hannah Arendt. O pensamento crítico torna-se um pensamento do estado de alerta. É em direção às condiçóes formadoras do "estado de exceção" - situação em que os ideais que orientam nossas instituiçôes são abandonados por razóes que abusivamente se pretendem legítimas - que se voltou boa parte do pensamento crítico. Para outros, como é o caso de Benjamin e Foucault, em cujas ideias Nietzsche está presente, o necessário parece ser abdicar das referências às promessas do esclarecimento e aos desvios que configuram o estado de exceção, atendo-se à crítica histórica simplesmente. É o que vemos relatado no curso de 1976, Em defesa da sociedade. Com respeito à "hipótese de Nietzsche", Foucault afirma:

E vocês teriam o outro sistema que tentaria, pelo contrário, analisar o poder político não mais de acordo com o esquema contrato-opressão, mas de acordo com o esquema guerra-repressáo. E, nesse momento, a repressão não é o que era a opressão em relação ao contrato, ou seja, um abuso, mas, ao contrário, o simples efeito e o simples prosseguimento de uma relaçáo de dominação. (FOUCAULT, 2005a, p. 24).

Ao encontrarmos a referência a Kant como o início da filosofia crítica, ou seja, da filosofia que se coloca como questão não a legitimação de um dogma, mas as condiçóes de possibilidade e os limites do conhecimento que produzimos, não devemos crer que Foucault seja adepto da compreensão kantiana da história. O motivo fundamental é que Kant inscreve a história na natureza, e Foucault é cético quanto a qualquer análise fundada em desígnios naturais, pois haveria também aí um recurso transcendente.

Teria Kant contrariado os seus próprios preceitos de não deduzir do mero conhecimento empírico o conhecimento metafísico? Questão formulada de forma precária, pois, para Kant, a história é um objeto passível de conhecimento científico - racional e empírico. Da mesma forma como “[...] um Kepler, que, de uma maneira inesperada, submeteu as excêntricas órbitas dos planetas a leis determinadas; e um Newton, que explicou essas leis por uma causa natural universal" (KANT, 2011, p.5), Kant está seguro, de acordo com o contexto de seu tempo, de poder aplicar o mesmo procedimento à história. Não é arbitrariamente que dizemos "aplicar" - do mesmo modo como Kant diz "submete" e "explicar em virtude de" -, pois são esses mesmos os procedimentos da razão que discernem nos dados empíricos as causalidades necessá- 
rias à produção do conhecimento científico. Vemos na Crítica da razão pura a seguinte passagem que o confirma:

[Galileu, Torricelli e Stahl] compreenderam que a razão só entende aquilo que produz segundo os seus planos prévios. A razão tem de tomar a dianteira com princípios, que determinam os seus juízos segundo leis constantes e deve forçar a natureza a responder às suas interrogaçóes em vez de se deixar guiar por esta. A não ser assim, as observaçóes feitas ao acaso, realizadas sem plano prévio, não se ordenam segundo a lei necessária, que a razão procura e de que necessita. (KANT, 2003, p. 27-28).

Uma vez que a razão indaga à natureza de que forma ela se faz presente na história, à semelhança do que Kepler, Newton, Galileu, Torricelli e Stahl encontraram como leis que regem a realidade empírica, Kant espera encontrar uma regularidade, a lei que conduz a história. Seu interesse é confirmar que essa regularidade deve nutrir as esperanças de que o mundo se torna cada vez mais conforme valores presentes em sua época. Essa é a tarefa, a atitude exigida pelo seu tempo, o Iluminismo.

Foucault, como homem de seu tempo, descrê de que se possa estabelecer para o conhecimento de todos os objetos do mundo o paradigma da física e da química. É contra o suposto cientificismo de todos os saberes, contra essa exacerbação da arquitetônica, que se dirigirá a crítica foucaultiana, a começar pelo cientificismo histórico, no qual vigora a ideia de que a história progride em conformidade com leis universais naturais. É preciso dedicar-se positivamente a identificar quão arbitrárias são muitas verdades que imaginamos de caráter científico, fazendo da crítica - não só contra a metafísica transcendente, como também contra qualquer exacerbação do cientificismo - um modo de devolver o arbitrário à sua positividade.

Fizemos até aqui uma série de afirmaçóes a respeito de Foucault, tomando o pensamento de Kant como base. Cabe ainda demonstrar de que maneira as posiçóes atribuídas a Foucault estão presentes em suas obras. Embora tenhamos partido de um de seus últimos textos, retornaremos à sua tese de doutorado, Folie et déraison, publicada com o título de Histoire de la folie à l'àge classique, para investigar qual é ali a referência da razão à história.

A despeito das distinçóes estabelecidas entre os dois filósofos, reconhecemos, em História da loucura, como trabalho fundamentalmente filosófico, a retomada do criticismo kantiano no sentido de um exame das condiçóes de 
possibilidade para a própria razão que conhece. Exceto o aspecto teleológico presente no filósofo do Iluminismo, a gênese da preocupação com as descontinuidades, fundamentais para as análises de Foucault da história, remete ao seu pensamento. $\mathrm{O}$ uso da expressão a priori, em As palavras e as coisas, torna a referência explícita, de sorte que, no lugar da teleologia, Foucault recorrerá ao procedimento crítico para melhor respeitar as vicissitudes da história. Não se trata de reconhecer o a priori para o conhecimento universalmente verdadeiro, mas o "a priori histórico" do conhecimento, o qual, em determinada época, assumimos como verdadeiro. Se Kant encontra, por um exame interno da razáo, o que concerne aos seus limites e o que é alheio, Foucault investiga, pelos limites traçados pela razão com a desrazão, ou seja, com as experiências que são a um tempo marginais e mundanas, o que concerne a ela própria, a razão. Em Kant, a metafísica é separada por um corte, mas é reservada para ela uma possibilidade legítima e propedêutica. Contra o que escapa à razão, porém permanece nesse mundo, Foucault revela que as suas exigências não relegam meramente as diferenças à indiferença, produzindo, nessa disputa de um mundo comum, efeitos práticos bem mais severos. Paradoxalmente, são por esses limites entre o campo da razão e da desrazão no mundo, é por essa topologia imanente que melhor encontramos a razão na história. É por uma análise do que parece externo, mas que não é alheio, a desrazão, que Foucault, em História da loucura, descreverá os efeitos de uma razão que, exacerbada, fugiu dos limites.

\section{A CIÊNCIA DAS ESSÊNCIAS PURAS}

Em um encontro no Japão, em 1970, publicado sob o título Loucura, literatura, sociedade, portanto 14 anos antes da publicação de O que é o Iluminismo?, no qual dialoga com Kant, Foucault afirma a respeito de Hegel coisas surpreendentemente semelhantes, as quais talvez sejam ainda mais precisas do que o são quanto a Kant:

Se Hegel expôs o conteúdo de toda a filosofia e, finalmente, o de todas as grandes experiências da história, isso não tinha outro objetivo senáo o de torná-lo imanente ao que chamamos presente, para provar que essas experiências históricas estão presentes em nós mesmos, ou, ainda, que estamos presentes nessas experiências. Tratava-se de uma magnífica síntese da interiorização sob forma de memória. [...] Hegel, afinal, não é apenas alguém que repete o que foi contado pelos murmúrios da história, mas alguém que transformou esses murmúrios para criar o próprio sentido da modernidade. (FOUCAULT, 2010, p. 254-255). 
Está novamente em questão compreender o que é a atitude moderna e ver que Foucault se utiliza da atitude de outro grande filósofo para explicar a sua própria. Para ele se tornará, igualmente, cada vez mais importante "transformar esses murmúrios para criar o próprio sentido da modernidade”.

Como Kant, Hegel apresenta tanto uma análise da atualidade quanto a implicação que tem com ela a filosofia - critérios que, como vimos, são fundamentais para a qualificação do que concerne à modernidade. Na verdade, tal distinção entre uma análise da atualidade e a determinação do que diz respeito à filosofia se torna precária, no caso de Hegel, visto que a modernidade é, para ele, o momento auge, quando o conhecimento da história universal se torna enfim possível. A modernidade é a hora em que assumimos o sentido histórico que nos guiou até o presente. Um pensamento filosófico em seu sentido radical não poderia, para Hegel, ser retirado de seu contexto, quando surge precisamente a evidência de tal elo. $O$ pensamento moderno, no qual a sua filosofia seria para ele o esplendor, é o instante desse reconhecimento e de resposta a esse elo. Portanto, aquilo que Foucault toma como critério para ver em Kant o início da modernidade, isto é, a investigação da atualidade, que é também a sua devolução ao horizonte permitido por essa atualidade, é um argumento pertencente às bases do pensamento hegeliano. É Hegel quem o formaliza enquanto parte necessária de um sistema ao mesmo tempo filosófico e histórico.

Afirmamos, quanto a Kant, que é preciso respeitar os limites estabelecidos frente a certas formas transcendentes de especulação metafísica (a prova da existência de Deus, a origem do universo) e que, para a tradição nele inspirada, a história se torna o caminho a ser percorrido em direção à reflexão imanente. Todavia, o que acontece quando encontramos, em Hegel, um pensamento assumidamente dedicado à metafísica e à história, crente em uma providência espiritual divina e, ao mesmo tempo, encarnado; um pensamento que, aliás, toma como ponto em comum a ambas - história e metafísica da transcendência - aquilo mesmo que possibilitava a Kant distingui-las, ou seja, a razão científica?

Poderíamos especular se a natureza dessa proposta não significa que Hegel tenha privilegiado o aspecto metafísico, em detrimento do histórico, mas é preciso não subestimar as suas análises históricas, pois Hegel teve clareza sobre as críticas de historiadores endereçadas aos filósofos, de que estes não fazem senão uma história do que convém aos seus conceitos e aos sistemas que criam. Hegel responde a essa crítica, admitindo a importância de ser preciso nas análises históricas, procedendo empiricamente. Em $A$ razão na história, o filósofo apresenta uma tipologia das formas de conhecimento histórico, pri- 
vilegiando aquelas cujas bases empíricas, principalmente o testemunho, são mais seguras. Assim, por exemplo, "Os comentários, de César, são uma obraprima de simplicidade de um grande gênio" (HEGEL, 1995, p. 12). Porém, Hegel devolve aos historiadores duas provocaçóes: a primeira, de que seja uma ingenuidade acreditar que não se trará consigo os conceitos de um pensamento reflexivo:

Mesmo o historiador normal e mediano, que de certa forma pretende e acredita manter-se compreensível e submisso ao fato, não age de modo passivo no seu pensar, recorrendo às suas categorias e encarando por meio destas os fatos; especialmente em tudo o que deve ser científico, a razão não pode adormecer, devendo utilizar-se da reflexão. (HEGEL, 1995, p. 18).

A segunda réplica de Hegel aos historiadores, argumento, aliás, central para o seu sistema, consiste em que, se o filósofo da história carrega consigo os conceitos de um pensamento reflexivo, isso náo se deve meramente aos seus caprichos, mas a uma exigência da história mesma, que, em sua concepção, não progride ao acaso, arbitrariamente. Hegel pretendeu acabar com a querela entre história e filosofia, mostrando que a história não progride senão racionalmente, conforme uma razão encontrada pela filosofia, mas não por ela criada. A razão está na história, e é pela filosofia que ela, enfim, se reconhece: "O único pensamento que a filosofia aporta é a contemplação da história; é a simples ideia de que a razão governa o mundo, e que, portanto, a história universal é também um processo racional” (HEGEL, 1995, p. 17).

Se o pensador da história empresta a ela os seus conceitos, isso não se deve a nada senáo ao reconhecimento de que há na história uma racionalidade que os requer. ${ }^{5}$ A distinção entre Hegel e Kant se impóe, então, à busca de clareza para a envergadura do tema dos laços entre a razão e a história. Diferentemente do que afirmou Kant, em Hegel não devemos nos deixar guiar pela razão contra os indícios de erro, das loucuras e dos fracassos do homem, os quais nos roubam as esperanças de um mundo melhor, enxergando um princípio que, para além de todas as evidências de crise, garantisse o real progresso humano. Tampouco o antagonismo na sociedade cumpre a mera função de motivar o uso da razão. Cabe-nos considerar que não há margem de erros, nem loucuras nem fracassos na história; que tudo que nela se passa pertence a

\footnotetext{
5 "Deve-se ter a crença real e insuperável de que a razão está na história e que o mundo da inteligência e da vontade consciente não está entregue ao acaso, porém deve-se mostrar à luz da ideia que se conhece" (em francês, "l'idée se sachant elle-même") (HEGEL, 1995, p. 17).
} 
um sentido dialético e, portanto, racional. O que Hegel faz é encontrar um lugar para a razáo em tudo que nos parece acidental e alheio, em tudo que parece contrariar o nosso discernimento, fazendo da razão não um domínio dentro de determinados limites estabelecidos pela crítica, e dos quais não devemos fugir, mas um sistema absoluto que abarca toda a história, seus grandes marcos e seus descaminhos - segundo os desígnios da Providência: "Devemos ter muito mais seriedade no conhecimento dos caminhos da Providência, os meios e manifestaçóes na história, relacionando-os àquele princípio geral" (HEGEL, 1995, p. 20). O real é racional.

Por mais ambiciosa que seja essa ideia, Hegel não se satisfaz em tomar a história por meio de leis que dizem respeito a uma natureza em sua abstração. Se Kant nos leva a discernir na história uma potência em progresso, a entrever uma forma em desenvolvimento que deixa, apesar de tudo, restos, Hegel incorpora todos os atos, preenche-a inteira. Ele quer fazê-lo com base em uma análise propriamente histórica, ou seja, cuidando de oferecer argumentos que atendam na forma e no conteúdo empírico ao seu sistema. Proceder empiricamente no exame da história é, enfim, o que distingue Kant e Hegel, e é igualmente o que fará com que Foucault, por esse aspecto, se situe mais próximo do segundo do que do primeiro. Em suma, Foucault assume a atitude crítica de Kant e a dedicaçáo hegeliana à empiria histórica, contudo, é preciso ver em que medida um pensamento que fala de dentro da filosofia crítica com o cuidado de situar-se na história pôde escapar a Hegel, que afirma:

O estudo da história universal resultou e deve resultar em que nela tudo aconteceu racionalmente, que ela foi a marcha racional e necessária do espírito universal; espírito cuja natureza é sempre idêntica e que a explicita na existência universal. Tal deve ser, como dissemos, o resultado do estudo da história. A história, porém, devemos considerá-la como ela é: devemos proceder de forma histórica, empírica. (HEGEL, 1995, p. 18).

Foucault não admite que uma ciência possa se fundar sobre um pressuposto transcendente, identificado pelo próprio Hegel ao domínio religioso. Com a atitude crítica de Kant, ele estabelece descontinuidades onde Hegel via um sentido teleológico estabelecido pela Providência, reconhecendo, no lugar da síntese proposta pelo filósofo do Idealismo absoluto, o primado empírico. Parece, enfim, que a saída de Foucault, para atender às próprias exigências dos dois filósofos da tradição, quando confrontados, foi se tornar mais crítico do 
que fora Kant e respeitar mais os acontecimentos do que fizera Hegel. Mas isso ainda não soluciona o problema principal.

Se Hegel é capaz de, a despeito dessa obrigação metafísica, proceder empiricamente, qual critério - da razão ou da empiria - pode assegurar-nos que uma análise histórica é absolutamente imparcial e livre de um compromisso com um plano externo ao seu campo de análise? Como evitar que a razão condicione o nosso acesso aos acontecimentos, ofuscando os indícios de ruptura? Para Hegel, conforme vemos em Fenomenologia do espírito, não há verdadeira filosofia que não seja ciência, e seu critério será tão abrangente que devemos nos perguntar se Foucault terá conseguido, em História da loucura, em seus outros livros e ainda nós, quem sabe, a ele escapar. O critério consiste em que, nas palavras do próprio Hegel, "[a] filosofia não considera a determinação inessencial, mas a determinação enquanto essencial” (HEGEL, 2002, p. 53). É possível fazer filosofia, sem pretender voltar-se ao que é essencial? Ele enfatiza: "Esse movimento das essencialidades puras constitui a natureza da cientificidade em geral" (HEGEL, 2002, p. 45). E, finalmente, por conclusão, Hegel entende que "[a] ciência exige atenção ao conceito como tal, às determinaçôes simples" (HEGEL, 2002, p. 61), isto é, exige a produção de conceitos que reúnam a multiplicidade do todo em essências inteligíveis capazes de demonstrar a racionalidade do real.

Em História da loucura, ainda que se trate para Foucault de realizar uma crítica da razão que se exacerbou, reivindicando o estatuto de ciência para domínios que teriam fugido de seus limites, é preciso guardar a suspeita de se não teria Foucault procedido por uma abordagem da história composta por análises de determinaçóes simples e essenciais, em suma, discriminando essências puras, conforme a exigência da cientificidade, como a entende Hegel. Isso não impóe a contestação das fontes empíricas sobre as quais a obra se baseia, mas faz com que nos perguntemos se é a quantidade e a diversidade das fontes empíricas que tornam um pensamento dedicado à história mais protegido da cientificidade a qual se visa criticar e que talvez esteja sempre implicada aos conceitos filosóficos.

A proposta foucaultiana de proceder com uma crítica contra os excessos da cientificidade significa proceder com uma crítica à filosofia? Por que meios, senáo com os conceitos com os quais trabalha a própria filosofia, tal empreendimento seria possível? De que modo um pensamento que pretende realizar uma crítica à exacerbação da pretensão científica o poderia fazer por conceitos, ou seja, de dentro da filosofia? 
Em “O que é o Iluminismo?”, quando Foucault responde a Kant, ele diz que a atitude crítica deve ser permanente e dirigir-se a um "atravessamento possível” ou ficar aux frontières. Todavia, isso não deve nos bastar para tomar a questão como resolvida. A questão é como Foucault responderá a Hegel, e isso ele o faz, não no ano de sua morte, mas já em sua tese de doutorado. Talvez seja preciso reconhecer que, a despeito de toda a riqueza e diversidade que encontramos reunida nessa obra de Foucault, trata-se de uma articulação entre os dois conceitos que formaram o título daquela tese de doutorado, antes que fosse publicada como História da loucura na idade clássica, conceitos que submetem a diversidade de tantos momentos da história e domínios de diferentes saberes a duas "essências puras": loucura e desrazão. Essa seria uma primeira hipótese, ou tese, na qual veríamos um trabalho implicado ao sistema hegeliano.

A atitude moderna, que investiga o momento no qual ela mesma se insere, investiga, enfim, o que lhe escapa, o seu momento de indecisão. Será preciso ainda investigar uma segunda hipótese, talvez uma antítese, proveniente da audaciosa conclusão de que talvez a filosofia náo seja, ao menos primordialmente, a produção de definiçôes essenciais, que não seja uma edificação de conceitos - ou que o pensamento já não seja apenas fiel ao domínio da filosofia. Ele pertenceria, por conseguinte, tanto pelo campo ao qual se dedica quanto por seu procedimento interno, não à criação do sentido da modernidade, com base na apropriação dos murmúrios da história, mas ao momento em que os murmúrios, deixados e reconhecidos em si mesmos, transformam à revelia da razão o sentido da modernidade. Momento de desrazão - dialética?

\section{A CONSTELAÇÃo DE IMAGENS}

Em História da loucura, Foucault transita por diversos domínios, entre os quais o teatro, a literatura, o direito, a medicina, a psiquiatria e, seja de que forma queiramos classificá-la também, notadamente, a filosofia. Para que possa justapor um ao outro, Foucault considera que os discursos versam sobre objetos definidos por cada parte à sua maneira, mas sobrepostos como se detivessem o mesmo estatuto, como se pertencessem a uma mesma trama. A cada passagem, é necessário demonstrar, por exemplo, que o discurso literário inaugura um objeto diferente daquele ao qual se dedicara o teatro, assim como a psiquiatria o faz quanto àquele que a determinado momento o Hospital Geral de Paris acolheu, mas também é necessário demonstrar que em algum horizonte eles hão de encontrar-se. Há entre tais paralelos uma distância que é 
preciso medir, mas cujos propósitos, ora científicos, ora artísticos, disciplinarmente organizados, seriam mais facilmente reconhecidos, caso o fossem assim apresentados. No entanto, Foucault não se atém a uma restrição disciplinar. Ele reúne em um mesmo plano, por exemplo, o movimento libertino do século XVII, o qual não sabemos se encerrado no cânone filosófico ou em uma postura de vida, a análises estatísticas sobre determinadas condiçóes de miséria econômica, em crises do século XVI e do século XVIII. São cosmos que se eclipsam no desenho amorfo de um conjunto que jamais se pode alcançar por um jogo de identidade entre os seus conteúdos internos. Nos hospitais, nos livros e nos tablados se encenam ideias audaciosas, as quais sugerem um tipo de lógica da livre associação nascida de espaços bem determinados e de procedimentos antissistemáticos que, finalmente, constituem essa história da loucura.

Somos levados a cogitar se a maior audácia não seria pretender que a obra seja uma coleçáo coerente. Afinal, que unidade narrativa pode haver, em uma história assim fragmentada? A obra se efetiva, portanto, interna e externamente ao seu campo de análise, não inteiramente entregue à razão com a qual é necessário proceder na produção de uma tese filosófica, uma razão compartilhada, tampouco entregue à desrazão, ao sabor dos juízos arbitrários de cada um. A filosofia crítica de Foucault carrega a desconfiança perante a hegemonia de uma forma de pensamento da qual não podemos de todo abdicar, a razão, mas que é preciso como que soltar as amarras e passar para além de seus limites, a fim de que se possa ser fiel ao seu objeto de interesse, a desrazão - objeto formado, para além da mera negatividade da razão, por um tanto de sonho, de imaginação, de paixão, de particularidades pessoais, em suma, dos restos das pretensôes de sistematização; de razões que nos escapam e nos encontram. A tese de Foucault será sem encadeamento conclusivo e chegará o mais próximo possível de seu objeto - sugestão de uma experiência de desrazão à qual não devemos, todavia, nos abandonar. "A loucura é ruptura absoluta da obra" (FOUCAULT, 2005b, p. 529).

História da loucura é um amálgama heterogêneo de objetos produzidos por discursos alheios uns aos outros, mas que Foucault reúne num só objeto, a loucura, o qual não pode ser senão fragmentado e, por isso, talvez mais bem revelado por uma imagem que por um conceito - objeto que é, destarte, heterotopicamente situado, que é como uma "constelação". Constelação de loucura. Loucura que é ruptura, fragmentação de obra:

Para a consciência ocidental, a loucura surge simultaneamente em pontos múltiplos, formando uma constelação que aos poucos se desloca e trans- 
forma seu projeto, e cuja figura esconde talvez o enigma de uma verdade. Sentido sempre despedaçado. (FOUCAULT, 2005b, p. 165).

Náo um conceito e uma definição de loucura, mas uma constelaçáo e o enigma de uma verdade - enigma que pede por uma decifração, mas que, finalmente, não cederá senão à justaposição de imagens. A trama que vemos desenrolar-se entre tantos domínios e através dos séculos envolve um objeto disperso em diferentes experiências. A constelação é traçada, em tão vasto espaço, revelando-nos a distância na qual parecemos preservados e à espera, quem sabe, de que uma verdade nos surpreenda, contornos de uma figura enfim mais específica do que a loucura: o "personagem louco" (FOUCAULT, 2005b, p. 159). Melhor se compreenderá quem é esse personagem por sua verdadeira forma alegórica, porém, o louco é um símbolo vazio. O que ele expressa: "O louco não é manifesto em seu ser: mas se ele é indubitável, é porque é outro" (FOUCAULT, 2005b, p. 183). Tratar-se-á, a cada vez, de esvaziá-lo do simbolismo com o qual ele já está tão carregado para remetê-lo aos seus tipos, aos seus casos e, finalmente, àqueles que se encarregam de classificá-los. O que caberá decifrar no símbolo do louco é a norma que o exclui. O louco é uma constelação de vidas fragmentadas e dispersas, que, com o tempo, perderam o direito à singularidade da imagem, não porque encontremos uma determinação essencial que as represente, mas porque, a partir do século XVII, elas já se encontram discriminadas.

Por uma leitura cuidadosa da obra, percebemos que não se trata de um mesmo personagem, e que o único critério capaz de qualificá-lo como parte de uma mesma história é o fato de que ele se distingue de todos os outros personagens os quais formam igualmente um só conceito ou um só personagem: o normal. Contudo, para náo falarmos mais em personagens, buscando ser fiéis aos círculos que associam essas estranhas singularidades e usurpam as suas especificidades, digamos que há toda uma classificação, um estudo de "classes" ao qual se dirige a Histórica da loucura: "Doentes venéreos, devassos, dissipadores, homossexuais, blasfemadores, alquimistas, libertinos" (FOUCAULT, 2005b, p. 102). E, além desses citados, há também o pobre, o leproso, o vagabundo, a prostituta, o alienado e o doente mental, é claro. Em suma, toda uma estranha classe, um conjunto que, porém, se assemelhará mais à enciclopédia de Borges, como vemos relatada em As palavras e as coisas, do que a um grupo com uma mesma proveniência, que tem um mesmo comportamento ou objetivo, uma classe que pudesse ser reunida por um critério intrínseco, uma 
essência pura. Por essa razão, o termo mais preciso utilizado por Foucault é "associal". O "associal" forma a classe ou sociedade de sujeitos estrangeiros entre os outros; o "associal" não se faz integrar e não é reconhecido; é plenamente vazio de status. O que é tão importante na obra, afinal, é o reconhecimento de que o que os atravessa lhes é extrínseco, ou seja, não é uma identidade de caráter, mas a própria história pretendida como processo civilizatório.

O critério que empiricamente permitirá a Foucault associar os "associais" é a prática, a qual se serve de uma verdadeira obsessão classificatória, que é, portanto, teoria posta em prática, do internamento. Aqueles náo encerrados em uma identificação, que não progridem como os outros, que não cumprem com o plano precisamente descrito por Hegel - "O [indivíduo] singular deve também percorrer os degraus-de-formação-cultural do espírito universal" (HEGEL, 2002, p. 41) - serão encerrados no interior de espaços geograficamente à margem da sociedade. À trama conceitual da desrazáo corresponde, destarte, a análise da prática concreta do internamento: "O internamento seria assim a eliminação espontânea dos 'associais" (FOUCAULT, 2005b, p. 79).

A História da loucura não é, imediatamente, a história de nossa ratio ocidental. Ela é a história de uma prática de exclusão dirigida a uma classe identificada sem um critério intrínseco, a despeito dos esforços racionais de classificação que lhe são dirigidos. Razão que cede, assim, em seu exercício de diferenciação, a um preconceito sobre a normalidade. Definir o bom uso da razão só é possível por meio da compreensão não diretamente da própria razão, mas do que constitui a sua falta, a sua carência, do que é, portanto, a linha divisória já traçada entre a normalidade e a alienação. Vemos uma razão que, à revelia de Kant, não se basta e não mais consegue se adiantar, que surge sempre atrasada; que, à revelia de Hegel, adormece.

A razão não é primordialmente uma faculdade que exercitamos ou não, e cujo exercício define o que nos constitui como homens, mas, ao menos para a modernidade, a exigência de um caminhar conjuntamente na história. $\mathrm{O}$ pertencimento é o critério que distingue a razão e a alienação, porém, ele é também um critério em contradição com a autonomia, com a maioridade que em Kant teria caracterizado o seu uso. A história da desrazão talvez seja a história do fracasso desse ideal de autonomia, da alienação de seus princípios e da forma como as suas consequências não apenas travestiram como inverteram tais princípios. À revelação desse processo de inversão dos propósitos da razão, de decifração dos seus códigos secretos, é que se dirige a arqueologia das prá- 
ticas de banimento: "Neste sentido, refazer a história desse processo de banimento é fazer a arqueologia de uma alienação" (FOUCAULT, 2005b, p. 81).

A respeito do conceito de arqueologia, é oportuno nos adiantarmos brevemente a um artigo de Foucault de 1971, intitulado "A monstruosidade da crítica”. Nele, em uma réplica ao crítico George Steiner, Foucault apresenta uma suposta origem do conceito. Ele o remete a Kant, afirmando que este “[...] utilizava esta palavra para designar a história daquilo que torna necessária uma certa forma de pensamento" (FOUCAULT, 2009, p. 323). Os editores dos Ditos e escritos de Foucault encontraram a referida passagem kantiana, onde descobrimos um sentido assaz diferente do empregado por Foucault. Não é a favor, mas contra a história que Kant emprega o conceito. Ele escreve: "Uma história filosófica da filosofia é possível não histórica ou empiricamente, mas racionalmente, ou seja, a priori. Pois ainda que ela estabilize fatos da Razão, não é do relato histórico que ela as toma, mas ela as tira da natureza da Razão humana sob forma de arqueologia filosófica” (KANT, 2009, p. 324). Portanto, mesmo que encontremos uma raiz terminológica, a arqueologia kantiana se dirige à "natureza da razão humana" e não à contingência de certa forma de pensamento. Não há nada na "arqueologia da alienação" de Foucault que a aproxime da "arqueologia da natureza da Razão humana”, de Kant. $\mathrm{Na}$ verdade, elas são opostas. Dedicar-se aos "processos de banimento" será justamente atentar à empiria recusada por Kant e que é decorrente da discriminação natural da Razão.

Tal argumentação abstrata, a qual pressupóe a partilha da normalidade na sociedade, com base na suposição de "códigos secretos" da razão, carece de um elemento empírico que a sustente. Afinal, como determinar se uma vida particular está ou não em conformidade com os desígnios da razão? Qual é o critério que induz a essa classificação? Como medir o pertencimento de um indivíduo ao todo? Qual é a medida que imediatamente permitirá inseri-lo na sociedade ou irá condená-lo à exclusão? Uma vez que a razão não diz o que ela mesma é, que a sua atribuição é tardia, a proposta de Foucault, em História da loucura, é encontrar não só as classes postas à margem dessa atribuição, como também os critérios ou o grande critério que socialmente a motiva, qual seja: "A família, com suas exigências, torna-se um dos critérios essenciais da razão" (FOUCAULT, 2005b, p. 90); "A instituição familiar traça o círculo de sua razão: para além dele surgem como ameaça todos os perigos do desatino (déraison, desrazão); lá o homem se entrega à insanidade e a todos seus furores" (FOUCAULT, 2005b, p. 91). 
Aqueles que podem e dedicam-se a montar uma família, que trabalham e responsabilizam-se por sustentá-la, atendem à exigência de uma vida em conformidade com a razão. O que há de normal nas famílias e o quanto pertencer a uma família é garantia de um comportamento admissível pela ordem social, porém, é algo que requereria um aprofundamento de análise que escapa à História da loucura e que igualmente nos escapa, de modo que a "família", embora pretendamos tomá-la como argumento empírico, se revela apenas mais uma entidade abstrata, uma classe em direçáo à qual podemos transferir o problema da pertença e da partilha, enfim, o problema da classificação da normalidade que guia problematicamente a prática de exclusão. No lugar de enfraquecer o argumento de Foucault, porém, isso apenas o reforça, já que náo se trata de justificar essa partilha, mas precisamente de revelar a sua arbitrariedade.

O que de nossa parte talvez caiba reconhecer é que, uma vez que o exame das práticas de exclusão recai sobre tal princípio, a família, não é Foucault quem primeiro o apontou. Se muito claramente ele está presente na tradição judaico-cristâ, no conjunto dos seus dogmas religiosos, e entre os gregos antigos pertencer ao Génos já fora o critério muito claro para a distinção entre o indivíduo que tem status e o que não possui, para a filosofia ele se torna na época moderna claramente e criticamente relevante com Marx e Feuerbach. Marx afirma que a divisão do trabalho, sobre a qual se mantém o sistema capitalista, serve e atende à unidade familiar. Ele atribui a essa ideologia, a da unidade familiar, que é, portanto, uma construção e não um desígnio natural, desdobrada no princípio da propriedade privada que materialmente lhe é correlato, as causas que fazem com que os homens se permitam alienar dos meios e dos bens de seu trabalho. Portanto, já em Marx, a família está diretamente implicada ao problema do trabalho e da alienação. Em Foucault, entretanto, o problema surge sem referência direta ao filósofo de $O$ capital:

Na história do desatino (déraison, desrazão), ela designa um evento decisivo: o momento em que a loucura é percebida no horizonte social da pobreza, da incapacidade para o trabalho, da impossibilidade de integrar-se no grupo; no momento em que começa a inserir-se nos problemas da cidade. (FOUCAULT, 2005b, p. 78).

Não se trata, para Foucault, de uma classe estabelecida por critérios econômicos e de produção do trabalho, apesar de serem homens em condiçóes especialmente sensíveis a tais problemas, mas de outro tipo de alienaçáo ligada, 
predominantemente, no lugar do mundo que produz, ao mundo que herda, composto mais por valores morais do que por valores de propriedade. Os "associais" não produzem como deveriam, como se espera de todos nós, mas a forma como oneram os demais não esgota a aversão que despertam. Há em Foucault, afinal, uma grande relevância do critério moral. O lugar claramente ocupado por Marx, na tradição do pensamento filosófico, e especificamente quanto ao problema da alienação, é por Foucault atribuído a Pinel. É o asilo onde habitam os loucos de Pinel, e não a fábrica onde trabalha o proletariado de Marx, o lugar arquetípico da alienação: "Se (Pinel) libertou o louco da desumanidade de suas correntes, acorrentou ao louco o homem e sua verdade. Com isso, o homem tem acesso a si mesmo como ser verdadeiro, mas esse ser verdadeiro só lhe é dado na forma da alienaçáo" (FOUCAULT, 2005b, p. 522).

Evidentemente, e dessa distinção não podemos mais escapar, Foucault contrapõe a razão pura à razão prática. Ele privilegia a segunda, mostrando que o império da razão científica está coadunado com uma grande violência prática de fundo moral. É mais pelo mecanismo de repartição explicitado no universo jurídico do que pelo progresso da ciência que compreendemos os desígnios da razão. Entretanto, para que possamos esclarecer esse argumento, não é a Kant nem a Hegel que devemos nos dirigir.

Entre Montaigne e Descartes algo se passou: algo que diz respeito ao advento de uma ratio. Mas é inquietante que a história de uma ratio como a do mundo ocidental se esgote no progresso do 'racionalismo'; ela se constitui em parte equivalente, ainda que mais secreta, desse movimento com o qual o Desatino (Déraison, Desrazão) mergulhou em nosso solo a fim de nele se perder, sem dúvida, mas também de nele lançar raízes. (FOUCAULT, 2005b, p. 48).

Não interessa à História da loucura fazer uma análise do racionalismo, mas reconhecer o que ficou à margem de suas ambiçôes e quais são as suas implicaçôes práticas e morais. Em Descartes, se o sonho pode ser admitido como hipótese para o sujeito que pensa, a loucura não. Essa é a origem da divisão. Assumindo a voz de Descartes, Foucault afirma: “[...] eu, que penso, não posso estar louco" (FOUCAULT, 2005b, p. 46); “[...] seria extravagante acreditar que se é extravagante” (FOUCAULT, 2005b, p. 47). E conclui: “[...] a loucura é excluída pelo sujeito que duvida” (FOUCAULT, 2005b, p. 47). Tal exclusão lógica da loucura, que pertence ao encadeamento da meditação cartesiana, culminará na exclusão social dos “associais" pelo internamento. As- 
sim, o exercício interno da razão, o qual prometia a libertação do sujeito de suas incertezas, levará à prática social de internamento. $\mathrm{O}$ exame interno das certezas da razão conduz ao internamento de todas as demais livres formas de lirismo do sujeito: “Mas, fazer o quê, 'são loucos...' Descartes, no movimento pelo qual chega à verdade, torna impossível o lirismo do desatino (déraison, desrazão)" (FOUCAULT, 2005b, p. 510).

Ainda que a referência a Descartes ofereça um marco esclarecedor, o que prevalece para Foucault é uma complexa análise histórica, e o que nela mais importa ver é a partilha moral em sua dimensão própria: "Todo interno é colocado no campo dessa valoração ética - e muito antes de ser objeto de conhecimento e de piedade, ele é tratado como sujeito moral" (FOUCAULT, 2005b, p. 62). Quanto à análise das ciências, o problema não é outro. Vemos na crítica de suas condiçóes de possibilidade que caberá pôr à prova a pretensão que possuem de neutralidade, de serem "razão pura", quanto ao risco de serem, na verdade, juízo moral:

A ciência "positiva" das doenças mentais e esses sentimentos humanitários que promoveram o louco à categoria de ser humano só foram possíveis uma vez solidamente estabelecida essa síntese. De algum modo ela constitui o a priori concreto de toda a nossa psicopatologia com pretensóes científicas. (FOUCAULT, 2005, p. 133).

$\mathrm{Na}$ origem das pretensóes científicas de tratamento do louco, como a priori histórico do saber da psicopatologia, está uma resposta já dada às inquietaçôes sociais, culturais e jurídicas. O sujeito normal não é um sujeito naturalmente dado, mas um sujeito que age em conformidade com as normas instituídas. Portanto, não está em questão definir a loucura ou negar a sua existência, como tampouco defender a anarquia social, substituindo a sociedade da razão por uma comunidade de loucos, mas reconhecer que as normas jurídicas não dizem respeito somente à esfera do Direito; elas dão as bases para a produção de saberes que têm a pretensão, mas que não atendem às exigências da cientificidade - sobretudo porque não realizam uma análise empírica neutra. $\mathrm{O}$ que interessa a Foucault não é discriminar o que positivamente constitui a loucura e o melhor modo de tratá-la, mas reconhecer que os saberes que se dedicaram à tarefa, ao longo de um grande quadro histórico, a época clássica, não se ativeram aos limites da ciência e que, no entanto, produziram uma série de objetos. 
Em suma, é sobre "[...] o fundo de uma experiência jurídica da alienação que se constituiu a ciência médica das doenças mentais" (FOUCAULT, 2005b, p. 130). Sobre uma razão moral, herdando objetos pretensamente naturais de uma esfera que delimita a cada vez quais devem ser as normas, as ciências do homem, principalmente a psiquiatria, buscaram legitimar-se como ciência positiva. Sáo essas anomalias da pretensão científica, as quais carregam também a identidade de todos nós - homens de razão -, que nos fizeram reconhecermo-nos, na modernidade, homens alienados.

Frisamos que Foucault investiga, pelos limites traçados pela razão com a desrazão, em experiências que são a um tempo marginais e mundanas, o que concerne à própria razão. Nessa torção que faz da crítica um procedimento mais radical, os limites são discriminados entre os acontecimentos na forma de descontinuidades que desestabilizam a razão. Posteriormente, afirmamos que os elementos que formam a constelação da desrazão, embora vinculados ao termo loucura por um uso social sem um princípio intrínseco, podem ser reconhecidos, para além de um mero caráter negativo, nos sonhos, na imaginação, nas paixóes que nos escapam ou nos atravessam, em experiências arquetípicas em Hölderlin, Nietzsche e Raymond Roussel - que anunciam a "renúncia da loucura" (FOUCAULT, 2005b, 349). Sem lançar mão de essências puras que submeteriam o trabalho histórico à estrutura metafísica característica da tradição filosófica que investigamos, mas como duplo de sua análise empírica capaz de abarcar razão e desrazão, Foucault estabelece como nova esfera a linguagem. Tal encadeamento temático possui igualmente um caráter formal, conduzindo o rigor de sua letra analítica quase a uma prosa poética.

A investigação da linguagem foge ao escopo deste trabalho, todavia, com o fim de apontar novas hipóteses, as quais nos parecem dever pressupor a trama aqui composta com Kant e Hegel, concluímos com uma provocativa passagem. Ela ressoa profundamente em trabalhos posteriores à História da loucura na idade clássica e que se voltam à compreensão da linguagem: "O desatino (déraison, desrazão) só pode aparecer por um instante, no momento em que a linguagem penetra no silêncio, em que o próprio delírio se cala, em que o coração é enfim devorado" (FOUCAULT, 2005b, p. 248). 
PRADO, Tomás. Kant, Hegel, Foucault and Unreason in History: the Philosophical Canon of the History of Madness. Trans/Form/Ação, Marília, v. 37, n. 2, p. 197-218, Maio/Ago., 2014.

\begin{abstract}
This article proposes to relate Kant's and Hegel's philosophy of history to the basis of Foucault's History of Madness in the Classical Age. We are not attempting to recognize the presence of a cosmopolitan or universal history, but trying to understand how critical thinking and philosophy as the science of pure essences appear in Foucault's historical intelligibility. The challenge of bringing together a diversity of experiences under the concept of unreason (déraison), which is the common thread of the book, suggests an attachment to tradition. However, the absence of an intrinsic criterion justifying the reference of that multiplicity to madness motivates a negative aspect to that concept and, positively, makes Foucault establish for his work an empirical primacy, in the form of a constellation of images. The procedure of the History of Madness that, with its interest in unreason, inaugurates the privilege given by the French philosopher to the analysis of discontinuities, leads us to recognize reason based on cases that escape its limits and the essences discerned by itself.
\end{abstract}

KEYWORDS: Reason. Unreason. Madness. Philosophy. History.

\title{
REFERÊNCIAS
}

FOUCAULT, M. Loucura, literatura, sociedade. In: Ditos e escritos. Trad. Vera Lucia Avelar Ribeiro. Rio de Janeiro: Forense Universitária, 2010. v. 1.

. A monstruosidade da crítica. In: Ditos e escritos. Trad. Inês Autran Dourado Barbosa. Rio de Janeiro: Forense Universitária, 2009. v. 3.

. O que são as luzes? In: . Ditos e escritos. Trad. Elisa Monteiro. Rio de Janeiro: Forense Universitária, 2008. v. 2.

. Em defesa da sociedade. Trad. M. E. Galvão, São Paulo: Martins Fontes, 2005a.

. História da loucura na idade clássica. Trad. J. T. Coelho Neto. São Paulo: Perspectiva, 2005b.

HEGEL, F. Fenomenologia do espirito. Trad. P. Meneses. Petrópolis: Vozes, 2002.

. HEGEL, F. Filosofia da história. Trad. M. Rodrigues e H. Harden. Brasília: Editora Universidade de Brasília, 1995.

KANT, I. Crítica da Razão Pura. Trad. A. Marins. São Paulo: Martin Claret, 2003.

Ideia de uma história universal de um ponto de vista cosmopolita. Trad. R. Terra. São Paulo: Martins Fontes, 2011.

Recebido em: 27/02/14

Aceito em: 02/04/14 
PRADO, T. 